\title{
Passivation of the surface of AZ31B magnesium alloy in solutions based on salts of rare-earth metals
}

\author{
A.A. Abrashov, ${ }^{1}$ (D) N.S. Grigoryan, ${ }^{1}$ (D) M.A. Simonova, ${ }^{1}$ (D) \\ T.A. Vagramyan ${ }^{1}$ (D) and I.A. Arkhipushkin ${ }^{2}$
}

${ }^{1}$ Federal State Budgetary Educational Institution of Higher Education "Russian ChemicalTechnological University named after D.I. Mendeleev”, Miusskaya sq., 9, 125047

Moscow, Russian Federation

${ }^{2}$ A.N. Frumkin Institute of Physical Chemistry and Electrochemistry, Russian Academy of Sciences, Leninsky pr. 31, 119071 Moscow, Russian Federation

*E-mail:abr-aleksey@yandex.ru

\begin{abstract}
A solution has been developed for applying protective-adhesive lanthanum-, manganesecontaining coatings under paintwork on the surface of magnesium alloy AZ31B instead of hightoxic chromate coatings, as well as independent anticorrosive coatings under mild operating conditions, for example, for inter-operation storage of products. A solution containing 1-6 g/l $\mathrm{La}\left(\mathrm{NO}_{3}\right)_{3} \cdot 6 \mathrm{H}_{2} \mathrm{O}$ and $0.5-2 \mathrm{~g} / 1 \mathrm{KMnO}_{4}$, allows at $\mathrm{pH} 2.0-3.0$ and at a temperature $18-30^{\circ} \mathrm{C}$ to form conversion coatings consisting of $\mathrm{La}_{2} \mathrm{O}_{3}, \mathrm{MnO}_{2}, \mathrm{MgO}, \mathrm{Mg}(\mathrm{OH})_{2}$ on the surface of AZ31B magnesium alloy in 2 minutes. Titanium-, zirconium- and lanthanum-, manganese-containing coatings can be used as adhesion layers under paintwork instead of high-toxic chromate coatings, and also as independent anticorrosive coatings under mild operating conditions, for example, for inter-operation storage of products. Using ellipsometry, it was found that the thickness of the cerium-containing coatings is $175 \pm 5 \mathrm{~nm}$. Corrosion tests in a salt-spray chamber according to ISO 4536 (SD test) ASTM B117 have shown that the developed lanthanum-, manganese-containing coatings are superior in protective ability to the currently widely used chromate coatings and are not inferior to titanium-, zirconium-containing coatings. The developed coatings also have good adhesion properties. Ti-, $\mathrm{Zr}$ - and La-, Mn-containing coatings in terms of protective characteristics and adhesion strength with paintwork are not only not inferior to the currently used chromate coatings but even surpass them.
\end{abstract}

Keywords: corrosion protection, conversion coatings, cerium-containing coatings, lanthanum-containing coatings, titanium-, zirconium-containing coatings, surface treatment, chromate-free passivation, rare-earth metals.

Received: May 23, 2021. Published: July 23, 2021

doi: $\underline{10.17675 / 2305-6894-2021-10-3-9}$

\section{Introduction}

The growing demand of the aviation, space, military and other industries for light materials with high strength characteristics, capable of withstanding high loads in various environments and operating conditions, predetermines the ever-increasing scale of 
application of magnesium alloys [1-3]. The disadvantages of magnesium and its alloys are low corrosion resistance and scrub resistance. The low corrosion resistance of magnesium alloys is due to the high negative values of their standard potentials $(-2.37 \mathrm{~V})$. In real chloride environment, for example, in a $3 \%$ solution of sodium chloride, the potential of the AZ31B magnesium alloy is $-1.38 \mathrm{~V}$, which is also much more negative than that of other structural metals and alloys [4].

In order to protect magnesium alloys from corrosion and wear and tear, protective coatings are applied to their surface: paint, galvanic (including conversion) hydride, anodic oxide, gas-plasma coatings, etc. [5-7]. According to [8], the leading place among the methods and means of protecting magnesium and its alloys belongs to conversion coatings, both independent and in combination with paintwork.

Chromatic coatings are widely used as adhesion layers under the paintwork before painting magnesium and its alloys.

Due to the high toxicity of chromating solutions, which contain hexavalent chromium compounds, and the conversion coatings formed in them, which also contain up to $200 \mathrm{mg} / \mathrm{m}^{2} \mathrm{Cr}^{6+}$, in many countries the use of conversion chromate coatings is significantly limited or prohibited [9-14].

In recent years, in world practice, as an alternative to chromate layers on magnesium and its alloys, conversion titanium- and/or zirconium-containing adhesive coatings have been used. Such coatings are formed from solutions based on hexafluorozirconic and hexafluorotitanic acids $[6,15-18]$. Along with this, salts of rare-earth metals, in particular cerium and lanthanum salts, which are ecologically safe and effective corrosion inhibitors of such metals as aluminum and zinc and their alloys, are described in the literature as corrosion inhibitors alternative to chromates [19-23]. In view of the foregoing, cerium- or lanthanum-containing conversion coatings can become a possible substitute for adhesive conversion chromate coatings.

At the Department of Innovative Materials and Corrosion Protection (Mendeleev University of Chemical Technology of Russia), technological processes for the deposition of titanium-, zirconium-containing conversion coatings were previously developed. Within the framework of this study, cerium- and lanthanum-containing coatings were developed and compared with titanium-, zirconium-containing and chromate coatings on the AZ31B magnesium alloy.

\section{Methods and Materials}

Magnesium plates AZ31B of the size of $3 \times 4 \mathrm{~cm}$ were used as samples.

To prepare the solutions, the chemical reagents of grades "pure", "chemically pure", and distilled water were used.

Passivating coatings were formed by immersing samples of magnesium alloy AZ31B in the test solution for a specified time, after which the samples were removed and dried by blowing hot air at a temperature of $80^{\circ} \mathrm{C}$ for 10 minutes. 
As objects of comparison, chromate and titanium-containing coatings were selected, for the formation of which the following solutions were used:

- $\mathrm{K}_{2} \mathrm{Cr}_{2} \mathrm{O}_{7} 40 \mathrm{~g} / 1 ; \mathrm{K}_{2} \mathrm{SO}_{4} 20 \mathrm{~g} / \mathrm{l} ; t=75^{\circ} \mathrm{C} ; 1-14 \min [24]$.

- $\mathrm{H}_{2} \mathrm{TiF}_{6} \quad 0.5-1 \mathrm{~g} / \mathrm{l} ; \quad \mathrm{H}_{2} \mathrm{ZrF}_{6} \quad 1.5-2 \mathrm{~g} / \mathrm{l} ; \quad \mathrm{HOOCCH}(\mathrm{OH}) \mathrm{CH}(\mathrm{OH}) \mathrm{COOH} \quad 1-2 \mathrm{~g} / \mathrm{l} ;$ $\left(\mathrm{NH}_{4}\right)_{6} \mathrm{Mo}_{7} \mathrm{O}_{24} 0.3 \mathrm{~g} / \mathrm{l} ; \mathrm{pH} 4-5 ; t=20-30^{\circ} \mathrm{C} ; 2-3 \min [6]$.

The protective ability of the coatings was determined by the "express drop method" using a $10 \mathrm{~g} / \mathrm{l}$ solution of lead acetate, $\mathrm{Pb}\left(\mathrm{CH}_{3} \mathrm{COO}\right)_{2}$. The criterion for assessing the quality of the coating was the time until the color of the control area under the drop changed from gray to dark black for the magnesium base. The "express drop method" using a solution containing $50 \mathrm{~g} / \mathrm{l}$ of $\mathrm{Pb}\left(\mathrm{CH}_{3} \mathrm{COO}\right)_{2}$ is intended for evaluating protective ability on galvanized steel [25]. When using a solution of this concentration in relation to a magnesium base, the color change of the control area under the drop of the solution occurred too quickly due to the high activity of magnesium. For this reason, it was not possible to visually assess the differences in the protective ability of magnesium-based coatings when using a solution of such a concentration. It has been experimentally established that for a visual assessment of the protective ability on a magnesium basis, the solution should be diluted (up to $10 \mathrm{~g} / \mathrm{l}$ ). The correctness of the application of the "drop method" using a diluted solution is due to the fact that it was used for comparative assessment of coatings and prompt rejection of unsuitable options. Subsequently, the protective ability of the developed coatings was determined by standard corrosion tests.

The thickness of the coatings was determined by an ellipsometric method using a spectroscopic ellipsometer by Sentech SENreseach (SENTECH Instruments GmbH, Krailling, Germany) 4.0 SER 800 with a high-speed monochromator. The measurements were carried out in the spectral range of wavelengths of $240-1000 \mathrm{~nm}$ at a goniometer angle of $70^{\circ}$. For calculations, a three-layer model was used, including two Drude-Lorentz layers and 1 Cauchy layer. The model parameters (thickness $d$, refractive index $n_{2}$ ) from the measured values $\Psi$ and $\Delta$ (inverse problem of ellipsometry) were determined by the software of the device in accordance with the selected mathematical model. The calculated result was considered valid if the result of the parameters of the physical model corresponded to the mathematical model and did not exceed the limits of the established errors [26]. The thickness measurement error was $\pm 5 \mathrm{~nm}$.

The composition of the surface layers was studied using X-ray photoelectron spectroscopy (XPS) on an OMICRON ESCA+XPS device (Germany) [27-30]. The panoramic spectra were also recorded after argon-ion etching of the coating in different depths. Thus, the composition of the coating at different distances from the substrate was determined. The pressure of the inert gas in the working chamber was maintained at this level, so that the ion energy and the ion current rate, and consequently, the etching rate, were constant. When analyzing the obtained spectra, it was considered that the analyzing beam penetrates the material to the depth of $5 \mathrm{~nm}$, i.e., the resulting spectra correspond to a layer of material $5 \mathrm{~nm}$ thick [31]. 
Corrosion tests of conversion coatings on magnesium surface using a saline solution according to ISO 4536 (SD test) were carried out in a solution simulating the composition of seawater (in g/l): $\mathrm{NaCl} 26.5 ; \mathrm{MgCl}_{2} 2.4 ; \mathrm{MgSO}_{4} 3.3 ; \mathrm{CaCl}_{2} 1.1 ; \mathrm{KCl} 0.73 ; \mathrm{NaHCO}_{3}$ 0.2; $\mathrm{NaBr}$ 0.28. This solution, in accordance with the method, was applied to the samples using a spray gun at a temperature of $23^{\circ} \mathrm{C}$, the relative humidity at the same time was $90 \%$ [32].

The adhesion of the coatings was determined by the normal detachment method using the PosiTest AT digital adhesion meter. The method is based on measuring the minimum breaking tension required to separate or rupture the coating in a direction perpendicular to the substrate surface [33].

Corrosion tests of magnesium samples in combination with powder paint were carried out in a salt spray chamber of Ascott S450iP (Great Britain) in accordance with the international standard ASTM B117 [34].

Polyester powder paint was applied to the samples with adhesion conversion coatings using an electrostatic coating pistol. Then, to melt the paint, the samples were placed in a drying oven for $10-15$ minutes at a temperature of $180-200^{\circ} \mathrm{C}$. After the melting process was completed, the samples were removed and cooled in air.

Current-voltage and impedance studies were carried out using an IPC potentiostat with an FRA attachment and a three-electrode glass cell thermostated at $25^{\circ} \mathrm{C}$ in $3 \% \mathrm{NaCl}$. The counter electrode was a titanium plate, the surface area of which significantly exceeded the overall area of the working electrode. The potentials were measured relative to a saturated silver-chloride electrode and then recalculated to the scale of a standard hydrogen electrode. The potential sweep rate when obtaining voltammograms was $50 \mathrm{mV} / \mathrm{s}$. The impedance was measured in a potentiostatic mode at a stationary potential in the frequency range $0.1 \mathrm{~Hz}-20 \mathrm{kHz}$ at a potential oscillation amplitude of $10 \mathrm{mV}$.

To analyze the equivalent circuits and calculate the denominations of their elements, the DCS program (Dummy Cell Solver), created by V.E. Kasatkin (IPCE RAS), was used. This program allows you to calculate the theoretical frequency dependence of the impedance of the selected circuit and compare it with the experimentally obtained dependence. The optimization of the nominal values of the elements of the selected equivalent circuit is performed according to the criterion of minimizing the relative error between the experimental and simulated values of the impedance vectors for each measurement in the investigated range.

\section{Results and Discussion}

Cerium and lanthanum salts such as phosphates, cinnamates and silicates [35-37], as well as nitrates and chlorides are described in the literature as corrosion inhibitors for aluminum and magnesium alloys [19,20,23,38].

Taking into account the manufacturability, safety, availability in the present work, nitrate salts of cerium and lanthanum $\left(\mathrm{Ce}\left(\mathrm{NO}_{3}\right)_{3} \cdot 6 \mathrm{H}_{2} \mathrm{O}\right.$ and $\left.\mathrm{La}\left(\mathrm{NO}_{3}\right)_{3} \cdot 6 \mathrm{H}_{2} \mathrm{O}\right)$ were chosen as the main components of the conversion solutions. 
According to the literature, the formation of a coating on the surface of magnesium in solutions based on cerium or lanthanum salts begins at the cathode areas of the surface as a result of an increase in $\mathrm{pH}$ in the solution adjacent directly to the metal surface due to oxygen reduction (metal corrosion with oxygen depolarization). The formation of films can be accelerated by introducing oxidizing agents into the solution, which catalyze the cathodic reaction [19-23].

In the present work with the accordance of literature data, hydrogen peroxide and potassium permanganate were tested as oxidants.

The experiments made it possible to determine the concentration regions of the solution components $\left(1-6 \mathrm{~g} / \mathrm{l} \mathrm{Ce}\left(\mathrm{NO}_{3}\right)_{3} \cdot 6 \mathrm{H}_{2} \mathrm{O}\right.$ or $\mathrm{La}\left(\mathrm{NO}_{3}\right)_{3} \cdot 6 \mathrm{H}_{2} \mathrm{O}$ and $15-20 \mathrm{ml} / 1 \mathrm{H}_{2} \mathrm{O}_{2}$ ), in which conversion homogeneous coatings had a good appearance and high adhesion strength to the substrate. However, the protective ability of the coatings is low - the color of a drop of the control solution changes on them within $15-20 \mathrm{~s}$.

It should be noted, that using $0.5-2 \mathrm{~g} / \mathrm{l}$ potassium permanganate instead hydrogen peroxide leads to an increase in the protective ability of the cerium-containing coatings formed up to 30-34 s and lanthanum-containing coatings up to 50-54 s, which is apparently explained by their lower porosity. At the same time, the permissible range of concentrations of rare-earth metal salts is preserved.

The above experiments were carried out at a working solution temperature of $18-25^{\circ} \mathrm{C}$. It was found that heating the solution to $40^{\circ} \mathrm{C}$ practically does not affect the protective ability of the coatings, further heating is undesirable, since it leads to some decrease in protective ability. Thus, heating the solution in the summer without damage to the deposited coatings is permissible up to $30^{\circ} \mathrm{C}$.

The study of the effect of the acidity of the solution on the protective ability of coatings showed that the acceptable $\mathrm{pH}$ values are in the range of 2.0-3.0, and the optimal values are in the range of $2.5-3.0 \mathrm{pH}$ units. At $\mathrm{pH}<2.0$ coatings are not formed. When the $\mathrm{pH}$ of the solution rises to $\mathrm{pH} \geq 4$, a precipitate of insoluble rare-earth metal compounds precipitates in the solution.

Taking into account possible transformations in accordance with the Pourbaix diagram for the $\mathrm{Ce}-\mathrm{H}_{2} \mathrm{O}_{2}$ and $\mathrm{La}-\mathrm{H}_{2} \mathrm{O}_{2}$ systems, the mechanism of formation of coatings in a solution with hydrogen peroxide at $\mathrm{pH}=2-3$ may be described by the following reactions:

$$
\mathrm{Ce}^{3+}+\mathrm{OH}^{-}+\frac{1}{2} \mathrm{H}_{2} \mathrm{O}_{2} \rightarrow \mathrm{Ce}(\mathrm{OH})_{2}^{2+}
$$

At the same time, the magnesium base is dissolved and the solution is alkalinized at the interface:

$$
\begin{gathered}
\mathrm{Mg} \rightarrow \mathrm{Mg}^{2+}+2 \mathrm{e}^{-} \\
\mathrm{H}_{2} \mathrm{O}_{2}+2 \mathrm{e}^{-} \rightarrow 2 \mathrm{OH}^{-}
\end{gathered}
$$

Magnesium ions, as well as $\mathrm{Ce}^{3+}$ ions unoxidized by hydrogen peroxide, form magnesium and cerium hydroxides: 


$$
\begin{gathered}
\mathrm{Mg}^{2+}+2 \mathrm{OH}^{-} \rightarrow \mathrm{Mg}(\mathrm{OH})_{2} \\
\mathrm{Ce}(\mathrm{OH})_{2}^{2+}+\mathrm{OH}^{-}+\mathrm{e}^{-} \rightarrow \mathrm{Ce}(\mathrm{OH})_{3}
\end{gathered}
$$

During subsequent drying, the resulting coatings are dehydrated and a mixed oxide is formed:

$$
\begin{gathered}
2 \mathrm{Ce}(\mathrm{OH})_{3} \rightarrow \mathrm{Ce}_{2} \mathrm{O}_{3}+3 \mathrm{H}_{2} \mathrm{O} \\
2 \mathrm{Ce}_{2} \mathrm{O}_{3}+\mathrm{O}_{2} \rightarrow 4 \mathrm{CeO}_{2} \\
\mathrm{Mg}(\mathrm{OH})_{2} \rightarrow \mathrm{MgO}+\mathrm{H}_{2} \mathrm{O}
\end{gathered}
$$

Lanthanum is included in the coating, apparently, in the form of an oxide formed by the following reactions:

$$
\begin{gathered}
\mathrm{La}^{3+}+3 \mathrm{OH}^{-} \rightarrow \mathrm{La}(\mathrm{OH})_{3} \\
2 \mathrm{La}(\mathrm{OH})_{3} \rightarrow \mathrm{La}_{2} \mathrm{O}_{3}+3 \mathrm{H}_{2} \mathrm{O}
\end{gathered}
$$

According to the above mechanism, the forming cerium-containing coating would appear to consist of oxides: $\mathrm{Ce}_{2} \mathrm{O}_{3}, \mathrm{CeO}_{2}$ и $\mathrm{MgO}$, and La-containing coatings - from oxides $\mathrm{La}_{2} \mathrm{O}_{3}$ and $\mathrm{MgO}$.

Potassium permanganate also acts as an oxidizing agent at the initial stage, which leads to a local increase in the $\mathrm{pH}$ value and allows the precipitation of $\mathrm{Ce}(\mathrm{OH})_{3} \mathrm{Or} \mathrm{La}(\mathrm{OH})_{3}$.

A decrease in the concentration of $\mathrm{H}^{+}$further contributes to the following reactions:

$$
\begin{gathered}
\mathrm{MnO}_{4}^{-}+2 \mathrm{H}_{2} \mathrm{O}+3 \mathrm{e}^{-} \rightarrow \mathrm{MnO}_{2}+4 \mathrm{OH}^{-} \\
\text {or } \\
\mathrm{MnO}_{4}^{-}+\mathrm{e}^{-} \rightarrow \mathrm{MnO}_{4}^{2-} \\
\mathrm{MnO}_{4}^{2-}+2 \mathrm{H}_{2} \mathrm{O}+2 \mathrm{e}^{-} \rightarrow \mathrm{MnO}_{2}+4 \mathrm{OH}^{-}
\end{gathered}
$$

In this regard, manganese oxide can also be included in the formed coatings along with magnesium, cerium and lanthanum oxides.

The chemical composition of the forming cerium- and lanthanum-containing coatings has been investigated. The survey XPS spectra of the coating formed in the working solution $\mathrm{Ce} / \mathrm{H}_{2} \mathrm{O}_{2}$ indicate the presence of oxygen, cerium, and magnesium in the coating. From the individual spectra of cerium (Figure 1a) and magnesium (Figure 1b), it can be seen that cerium is present in the coating in the form of $\mathrm{Ce}_{2} \mathrm{O}_{3}$ and $\mathrm{CeO}_{2}$, and magnesium in the form of $\mathrm{MgO}$ and $\mathrm{Mg}(\mathrm{OH})_{2}$. Lanthanum from the working solution $\mathrm{La} / \mathrm{H}_{2} \mathrm{O}_{2}$, as expected, is included in the coating in the form of $\mathrm{La}_{2} \mathrm{O}_{3}$ (Figure 2). Manganese from the working solutions $\mathrm{Ce} / \mathrm{KMnO}_{4}$ and $\mathrm{La} / \mathrm{KMnO}_{4}$ is included in the coating in the form of manganese(VI) oxide (Figure 3 ). These data are consistent with the above-described mechanism of coating formation. 

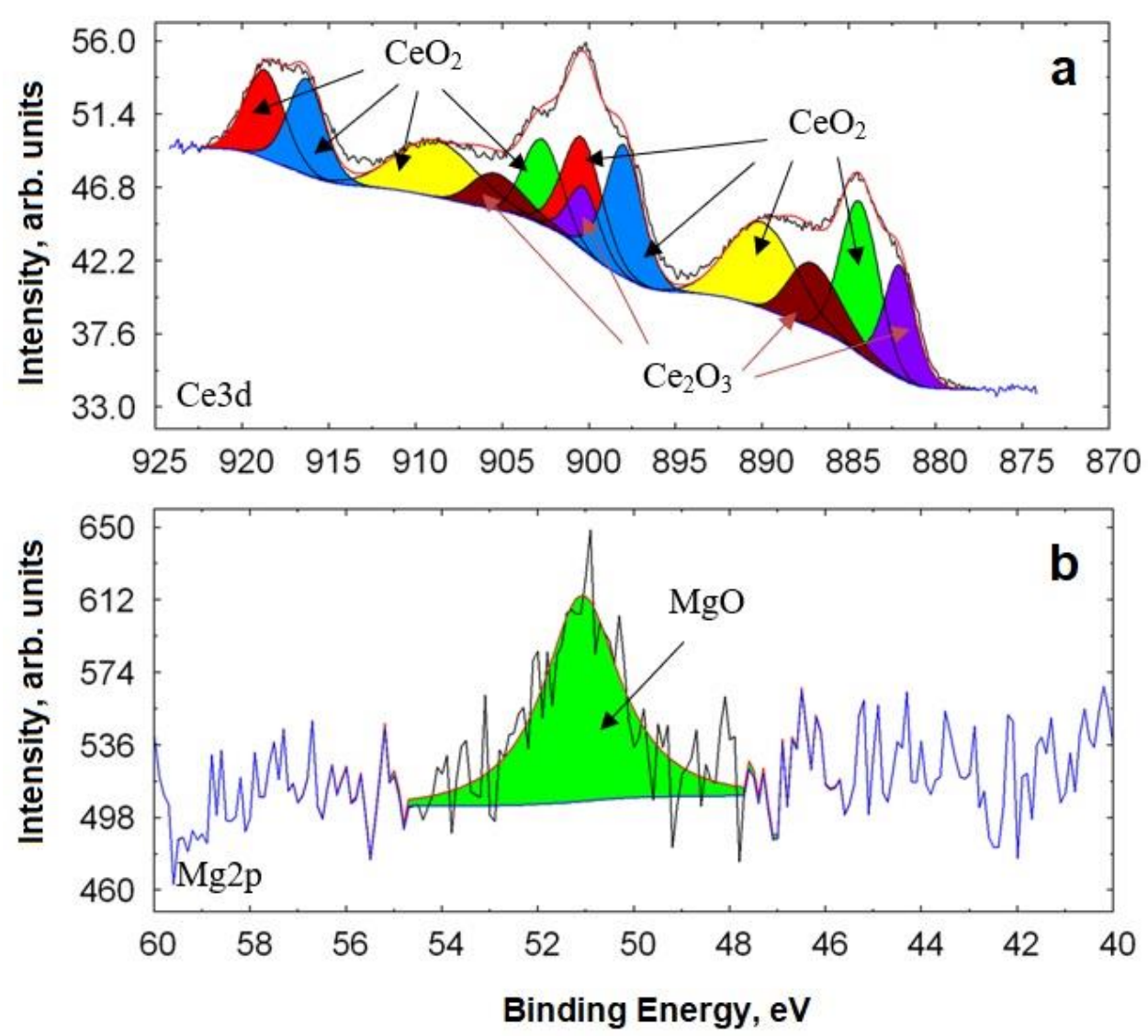

Figure 1. Individual XPS spectra of cerium (a) and magnesium (b) in the coating.

The spectra in Figures 1 and 3 show that, in the presence of hydrogen peroxide in the solution, 10 times less magnesium is included in the coating than in the presence of potassium permanganate, and the proportion of $\mathrm{Ce}(\mathrm{IV})$ oxides significantly increases: the ratio $\mathrm{Ce}(\mathrm{IV}) / \mathrm{Ce}(\mathrm{III})$ in the coating in this case increases 3.5 times (Table 1). This is most likely due to the greater oxidizing ability of potassium permanganate in relation to magnesium: the standard potentials of oxidants are $E_{\mathrm{H}_{2} \mathrm{O}_{2} / 2 \mathrm{OH}^{-}}^{0}=+0.88 \mathrm{~V}$ and $E_{\mathrm{MnO}_{4}^{-} / \mathrm{MnO}_{2}}^{0}=+1.692 \mathrm{~V}$, respectively.

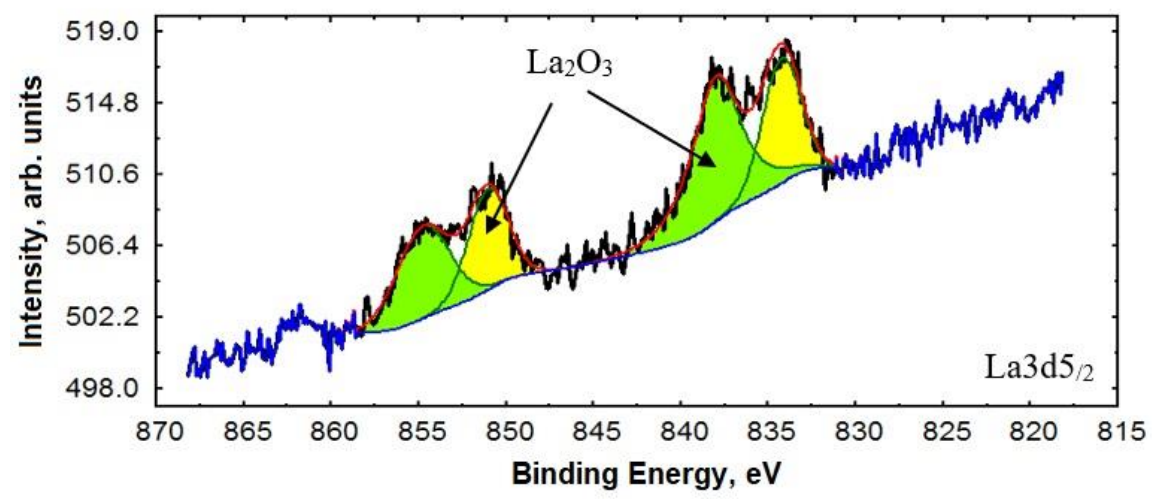

Figure 2. Individual XPS spectra of lanthanum in the coating. 
Table 1. Chemical composition of the coatings (X-ray photoelectron spectroscopy (XPS)).

\begin{tabular}{ccc}
\hline Name & Peak name & Quantitative composition, \% \\
\hline \multirow{2}{*}{ Cerium } & $\mathrm{Ce} / \mathrm{H}_{2} \mathrm{O}_{2}$ & \\
\hline Oxygen & $\mathrm{Ce} 3 \mathrm{~d}^{4+}$ & 7.89 \\
$\mathrm{Ce}^{2} \mathrm{~d}^{3+}$ & 2.40 \\
\hline Magnesium & $\mathrm{O} 1 \mathrm{~s}$ & 86.56 \\
\hline & $\mathrm{Mg} 2 \mathrm{p}$ & 3.14 \\
\hline Cerium & $\mathrm{Ce} / \mathrm{KMnO}_{4}$ & 2.02 \\
\hline Oxygen & $\mathrm{Ce} 3 \mathrm{~d}^{4+}$ & 0.85 \\
\hline Manganese & $\mathrm{Ce} 3 \mathrm{~d}^{3+}$ & 60.28 \\
\hline Magnesium & $\mathrm{O} 1 \mathrm{~s}$ & 6.20 \\
\hline
\end{tabular}
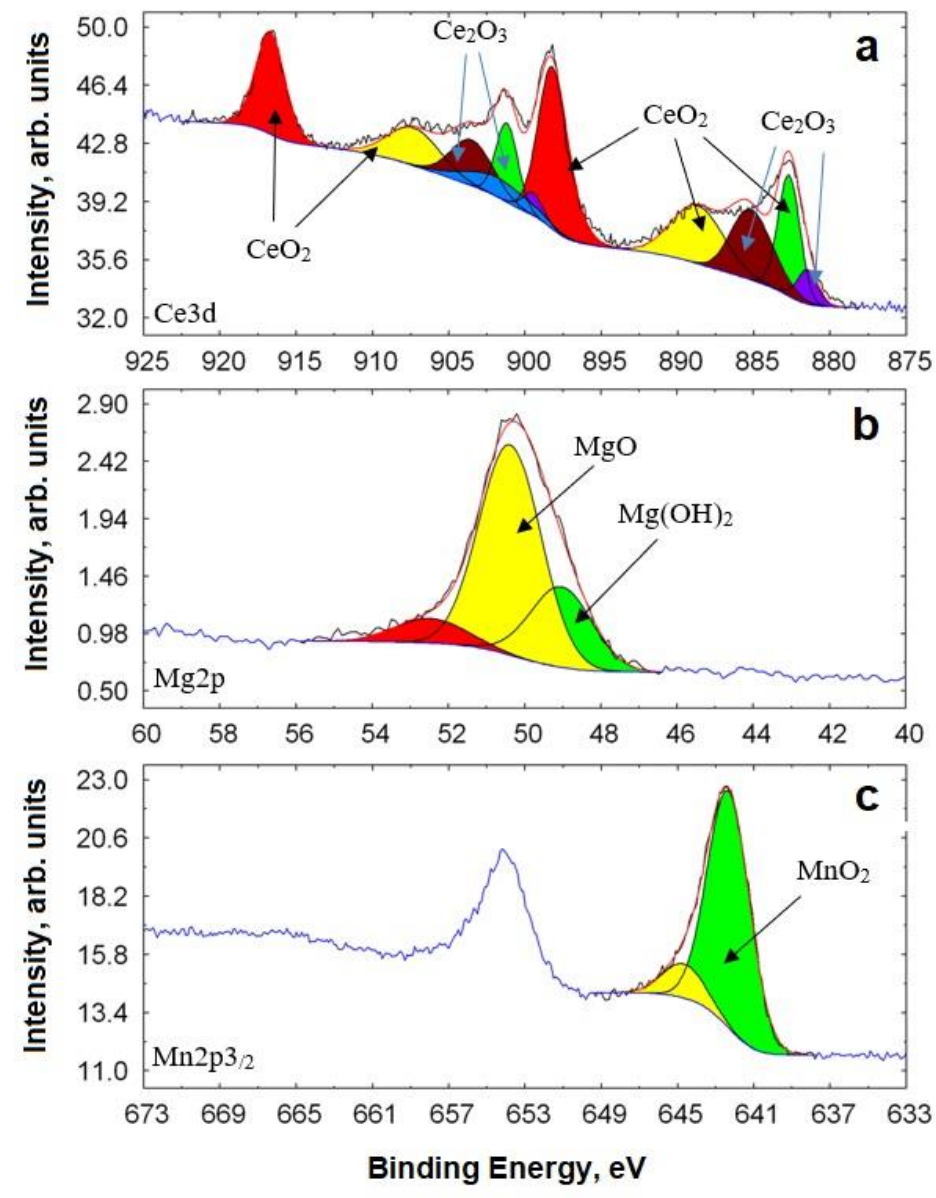

Figure 3. Individual XPS spectra of cerium (a) magnesium (b) and manganese (c) in the coating. 
Figure 4 shows the results of corrosion tests according to ISO 4536 (SD test) of magnesium samples with cerium- and lanthanum-containing coatings, as well as chromate and $\mathrm{Ti}, \mathrm{Zr}$-containing layers. It can be seen that $\mathrm{La}, \mathrm{Mn}$-containing coatings have the greatest protective ability. The first local spot of corrosion appeared after 30 hours of testing. Ceand $\mathrm{Ce}, \mathrm{Mn}$-containing coatings are characterized by the least protective ability: corrosion products begin to appear after 6 and 8 hours, respectively. Samples with chromate and Ti, $\mathrm{Zr}$-containing coatings begin to corrode after 20 and 24 hours of exposure under the salt drops, respectively. It should be noted that the first local spot of corrosion on a magnesium base without coating appear after 0.5 hours of corrosion tests.

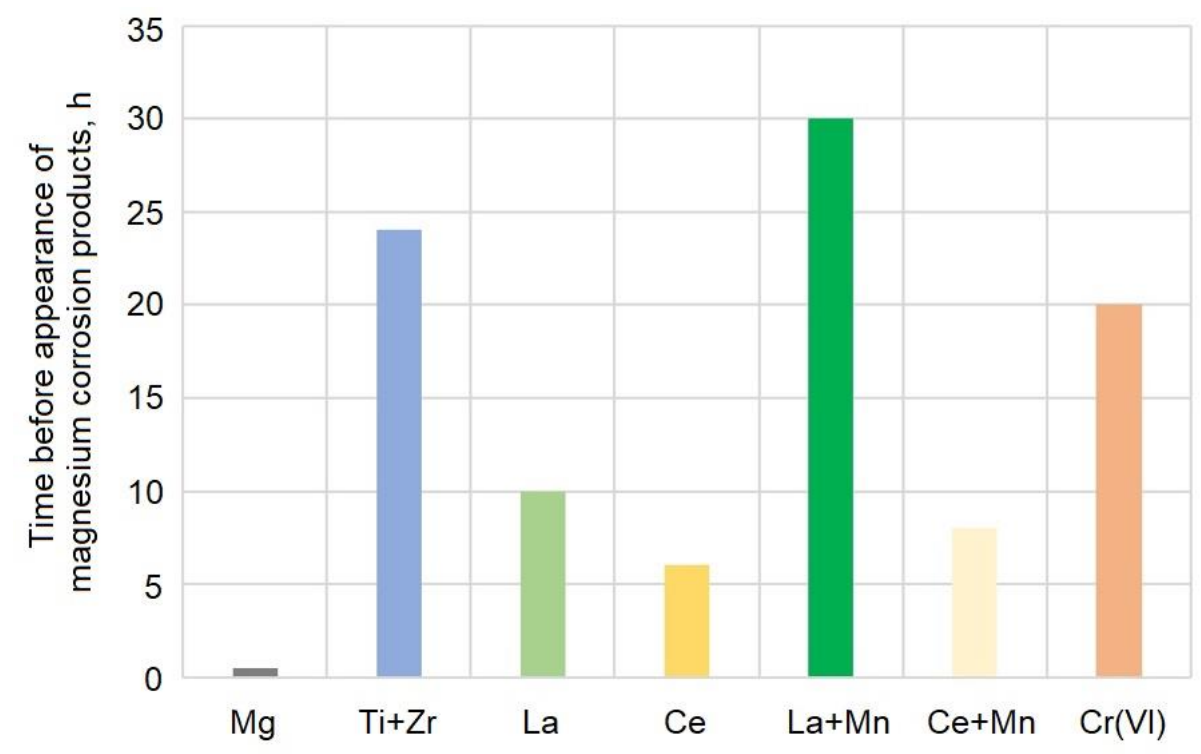

Figure 4. Saline drop test results.

With the help of ellipsometry, the thicknesses of the developed and selected as objects of comparison conversion coatings on magnesium alloy were determined (Figure 5).

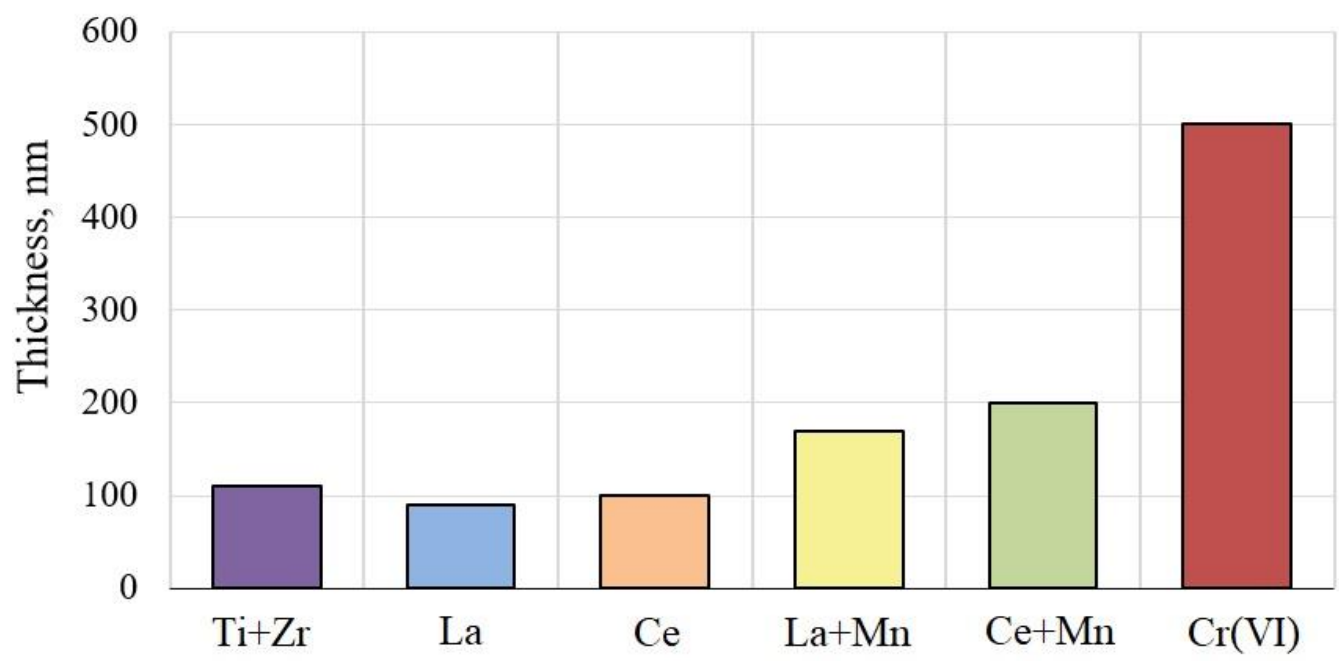

Figure 5. Thickness value depending on the type of coating. 
It should be noted that at a significantly lower thickness, La, Mn-containing coatings are superior to chromate coatings in terms of protective ability, and $\mathrm{Ti}, \mathrm{Zr}$-containing coatings are comparable to them.

In this work, impedance spectroscopy was also used to compare the protective characteristics of conversion coatings.

Protective coatings can be described by an equivalent circuit (Figure 6), consisting of active resistance $\left(R_{0}\right)$, which is the resistance of the electrolyte, the capacitance of the electric double layer $\left(C P E_{1}\right)$, which is the geometric capacity of the conversion film, and the active resistance $\left(R_{1}\right)$, which is the polarization resistance of the conversion coating, the pseudoinductive resistance $\left(R_{2}\right)$, which is the polarization resistance to the corrosion process, and the pseudo-induction capacitance $\left(C P E_{2}\right)$, which is the capacitance of the metal/coating interface.

Nyquist diagrams (hodographs) for magnesium alloy samples with various conversion coatings are shown in Figure 6. Parameter values calculated according to the equivalent circuit are shown in Table 2.

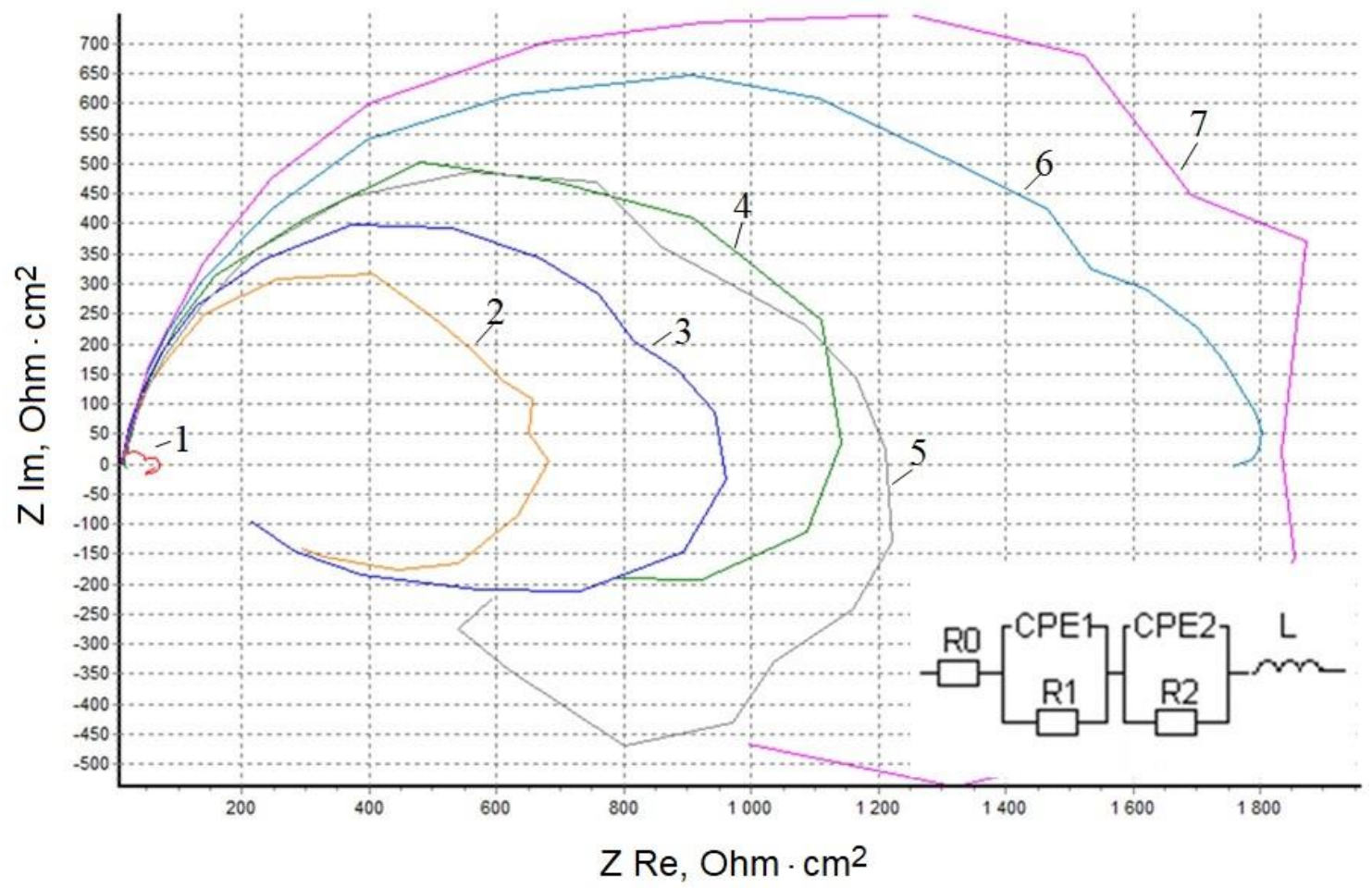

Figure 6. Nyquist diagrams and equivalent circuit for magnesium samples with protective coatings: 1 - uncoated $\mathrm{Mg} ; 2$ - Ce; 3 - Ce+Mn; $4-\mathrm{Cr}(\mathrm{VI}) ; 5-\mathrm{La} ; 6-\mathrm{Ti}+\mathrm{Zr} ; 7$ - La+Mn.

It is known that hodographs show charge transfer resistance from solution to metal and vice versa, so the larger the hodograph loop, the more hindered this process is, and, therefore, the hodographs can be used to assess the barrier characteristics of the coatings. The given hodographs indicate that the greatest difficulties in charge transfer occur in the case of a La, 
Mn-containing coating. The hodograph radii of samples with $\mathrm{La}, \mathrm{Mn}$ - and $\mathrm{Ti}, \mathrm{Zr}$-containing coatings are comparable.

Table 2. Parameter values calculated according to the equivalent circuit.

\begin{tabular}{ccccccccc}
\hline System & $\mathbf{E}, \mathbf{m V}$ & $\boldsymbol{R}_{\mathbf{0}}, \mathbf{O h m}$ & $\boldsymbol{R}_{\mathbf{1}}, \mathbf{O h m}$ & $\boldsymbol{C P E} \mathbf{T 1}$ & $\boldsymbol{C P E} \mathbf{f 1}$ & $\boldsymbol{R}_{\mathbf{2}}$ Ohm & $\boldsymbol{C P E} \mathbf{T 2}$ & $\boldsymbol{C P E} \mathbf{f} 2$ \\
\hline $\mathrm{Cr}$ & -1313 & 15.1668 & -762.697 & -0.00022 & 1 & 1409.31 & $2.14 \cdot 10^{-5}$ & 0.897291 \\
$\mathrm{Ce}$ & -1323 & 13.2585 & -420.98 & -0.00028 & 1 & 663.433 & $3.89 \cdot 10^{-6}$ & 0.938318 \\
$\mathrm{Ti}-\mathrm{Zr}$ & -1358 & 11.1396 & 260.47 & 0.00012 & 1 & 1522.9 & $3.34 \cdot 10^{-6}$ & 0.888408 \\
$\mathrm{Ce}-\mathrm{Mn}$ & -1363 & 13.3263 & -624.023 & -0.00046 & 1 & 863.098 & $4.40 \cdot 10^{-6}$ & 1 \\
$\mathrm{La}$ & -1298 & 20.6885 & -736.783 & -0.00043 & 1 & 1139.49 & $1.81 \cdot 10^{-6}$ & 1 \\
La-Mn & -1313 & 8.03443 & -1314.69 & -0.00014 & 1 & 2084.13 & $6.45 \cdot 10^{-6}$ & 0.84411 \\
$\mathrm{Mg}$ & -1318 & 8.51841 & -36.2972 & $-4.29 \cdot 10^{-3}$ & 1 & 75.1038 & $9.22 \cdot 10^{-4}$ & 1 \\
\hline
\end{tabular}

It should be noted that the results of impedance spectroscopy are consistent with the above results of corrosion tests.

Corrosion tests (ASTM B117) in a salt spray chamber of AZ31B magnesium alloy samples with applied conversion coatings, painted with polyester powder paint (Ecocolor PE RAL 9016/P), were carried out. The thickness of the paintwork was 90-100 microns.

Tests have shown that the developed coatings in terms of protective ability satisfy the requirements for adhesive layers under the paintwork, since the width of corrosion penetration from the place of incision in these cases does not exceed $2 \mathrm{~mm}$ after 240 hours of testing according to the international standard ISO 9227 (Table 3).

Table 3. Results of corrosion tests.

\begin{tabular}{ccccc}
\hline No. & Coating & $\begin{array}{c}\text { The width of corrosion } \\
\text { type }\end{array}$ & $\begin{array}{c}\text { penetration from the place of } \\
\text { incision, } \\
\text { (ISO 9227) }\end{array}$ & $\begin{array}{c}\text { Corrosion spread assessment from the place } \\
\text { of incision (ASTM D 1654-08) }\end{array}$ \\
\cline { 4 - 5 } & & 9.58 & $\begin{array}{c}\text { Corrosion spread from the } \\
\text { place of incision, mm }\end{array}$ & $\begin{array}{c}\text { Class } \\
\text { (from 0 to 10) }\end{array}$ \\
\hline 1 & $\mathrm{Mg}$ & 0.2 & 6.32 & 4 \\
2 & $\mathrm{Ti}+\mathrm{Zr}$ & 0.86 & 0.1 & 9 \\
3 & $\mathrm{Ce}$ & 0.6 & 1.08 & 7 \\
4 & $\mathrm{La}$ & 0.78 & 0.56 & 8 \\
5 & $\mathrm{Ce}+\mathrm{Mn}$ & 0.26 & 1.03 & 7 \\
6 & $\mathrm{La}+\mathrm{Mn}$ & 0.15 & 0.16 & 9 \\
7 & $\mathrm{Cr}(\mathrm{VI})$ & & 0.2 & 9 \\
\hline
\end{tabular}


It should be noted that the smallest depth of corrosion penetration under the paintwork film from the place of incision is observed for samples with adhesion chromate, $\mathrm{Ti}, \mathrm{Zr}$ - and $\mathrm{La}, \mathrm{Mn}$-containing coatings (class 9 on a ten-point scale according to the American standard ASTM D 1654-08).

The pull-off adhesion strength of the LCP to the surface of AZ31B with an adhesive sublayer (the "fungi" method), is shown in Table 4.

Table 4. The results of determining the adhesion strength of coatings to the substrate.

\begin{tabular}{ccccc}
\hline \multirow{2}{*}{$N$ No } & Coating type & \multicolumn{2}{c}{ Adhesion strength, MPa } & \multirow{2}{*}{$\begin{array}{c}\text { The decrease in } \\
\text { adhesion, \% }\end{array}$} \\
\cline { 3 - 4 } & & Before corrosion tests & After corrosion tests (240 h) & \\
\hline 1 & $\mathrm{Mg}$ & 6.14 & 2.42 & 60.6 \\
2 & $\mathrm{Ti} / \mathrm{Zr}$ & 13.83 & 11.61 & 16.0 \\
3 & $\mathrm{Ce}$ & 10.42 & 4.24 & 59.3 \\
4 & $\mathrm{La}$ & 12.7 & 6.42 & 49.4 \\
5 & $\mathrm{Ce}, \mathrm{Mn}$ & 11.19 & 8.35 & 25.4 \\
6 & $\mathrm{La}, \mathrm{Mn}$ & 13.65 & 11.18 & 18.1 \\
7 & $\mathrm{Cr}$ & 13.15 & 10.42 & 20.8 \\
\hline
\end{tabular}

It can be seen that the adhesion strength of the samples with titanium-, zirconium- and lanthanum-, manganese-containing adhesive coatings is higher than that of the sample with chromate coating: 13.83 and 13.65 versus $13.15 \mathrm{MPa}$. It should be noted that the decrease in adhesion (\%) after 240 hours of corrosion tests in a salt spray chamber for these coatings is $16.0 \%, 18.1$ and $20.8 \%$, respectively.

\section{Conclusion}

A solution containing 1-6 g/l La(NO 3$)_{3} \cdot 6 \mathrm{H}_{2} \mathrm{O}, 0.5-2 \mathrm{~g} / 1 \mathrm{KMnO}_{4}$, allows at $\mathrm{pH} 2.0-3.0$ and at a temperature $18-30^{\circ} \mathrm{C}$ to form on the surface of AZ31B magnesium alloy conversion coatings $175 \pm 5 \mathrm{~nm}$ thick consisting of $\mathrm{La}_{2} \mathrm{O}_{3}, \mathrm{MnO}_{2}, \mathrm{MgO}, \mathrm{Mg}(\mathrm{OH})_{2}$ for 2 minutes.

Titanium-, zirconium- and lanthanum-, manganese-containing coatings in terms of protective characteristics and adhesion strength with paintwork are not only not inferior, but also surpass the currently used chromate coatings.

Titanium-, zirconium- and lanthanum-, manganese-containing coatings can be used as adhesion layers under paintwork instead of high-toxic chromate coatings, as well as independent anticorrosive coatings in light operating conditions, for example, for interoperative storage of products. 


\section{Acknowledgements}

The work was supported by the Mendeleev University of Chemical Technology of Russia. Project Number X-2020-028.

\section{References}

1. N.V. Trofimov, A.A. Leonov, V.A. Duyunova and Z.P. Uridiya, Foundry magnesium alloys (review), Trudy VIAM, 2016, 12, no. 48, 3-12 (in Russian). doi: 10.18577/23076046-2016-0-12-1-1

2. E.N. Kablov, Aviation materials science: results and prospects, Vestnik Rossiiskoi Akademii Nauk, 2002, 72, no. 1, 3-12 (in Russian).

3. E.F. Volkova and V.A. Duyunova, On the current trends in the development of magnesium alloys, Tekhnologiya legkikh splavov, 2016, no. 3, 94-105 (in Russian).

4. V.C. Sinyavskii, Features of corrosion of magnesium alloys in wide application, Tekhnologiya legkikh splavov, 2011, no. 2, 77-85 (in Russian).

5. S.L. Sinebryukhov, M.V. Sidorova, V.S. Egorkin, P.M. Nedozorov, A.Yu. Ustinov and S.V. Gnedenkov, Anticorrosive antifriction coatings on magnesium alloys for aviation, Vestnik DVO RAN, 2011, no. 5, 95-105 (in Russian).

6. A.A. Abrashov, N.S. Grigoryan, M.A. Simonova and N.A. Asnis, Adhesive conversion coatings for paint and varnish coatings on magnesium alloys, Tsvetnyye metally, 2019, no. 10, 66-71 (in Russian). doi: 10.17580/tsm.2019.10.11

7. N.P. Andreeva, Yu.I. Kuznetsov, A.M. Semiletov and A.A. Chirkunov, Formation of passive films on magnesium in alkaline solutions and adsorption of organic acid anions on them, Korroz.: Mater., Zashch., 2017, 2, 41-48 (in Russian).

8. J. Zhang and $\mathrm{Ch}$. Wu, Corrosion and protection of magnesium alloys - a review of the patent literature, Recent Pat. Corros. Sci., 2010, 2, 55-68.

9. V.V. Okulov, Environmental, technological and economic aspects of the replacement of hexavalent chromating (passivation) solutions, Gal'vanotekhnika $i$ obrabotka poverkhnosti, 2005, 13, no. 2, 35-41 (in Russian).

10. Directive 2000/53/EC of the Parliament and the Council of Europe on September 18, 2000 "End-of-live-vehicles", Official Journal of the European Communities L269. 3443.

11. Replacement hexavalent chromium in automotive industry for ELV Directive. H.A. Bhatt, technical paper, Sur/Fin. 6/2002.

12. Directive 2011/65 / EC (RoHS II) of the European Parliament and of the Council of 8 June 2011 on the restriction of the use of certain hazardous substances in electrical and electronic equipment.

13. Directive 2002/96 / EC of the European Parliament and of the Council of 27 January 2003 on waste electrical and electronic equipment. 
14. Regulation (EC) No 1907/2006 of the European Parliament and of the Council of 18 December 2006 concerning the registration, assessment, authorization and limitation of chemicals (REACH), the establishment of the European Chemicals Agency.

15. X.B. Chen, N. Birbilis and T.B. Abbott, Review of corrosion-resistant conversion coatings for magnesium and its alloys, Corrosion, 2011, 67, no. 3. doi: $10.5006 / 1.3563639$

16. A. Yi, J. Du, J. Wang, S. Mu, G. Zhang and W. Li, Preparation and characterization of colored Ti/Zr conversion coating on AZ91D magnesium alloy, Surf. Coat. Technol., 2015, 276, 239-247. doi: $10.1016 /$ j.surfcoat.2015.06.069

17. E. Gulbrandsen, J. Taftø and A. Olsen, The passive behaviour of $\mathrm{Mg}$ in alkaline fluoride solutions. Electrochemical and electron microscopical investigations, Corros. Sci., 1993, 34, no. 9, 1423-1440. doi: 10.1016/0010-938X(93)90238-C

18. S. Verdier, N. van der Laak, S. Delalande, J. Metson and F. Dalard, The surface reactivity of a magnesium-aluminium alloy in acidic fluoride solutions studied by electrochemical techniques and XPS, Appl. Surf. Sci., 2004, 235, no. 4, 513-524. doi: 10.1016/j.apsusc.2004.03.250

19. Ch. Lin, Ch. Changguo, W. Ningning, W. Jimin and D. Ling, Study of cerium and lanthanum conversion coatings on AZ63 magnesium alloy surface, Rare Metal Materials and Engineering, 2015, 44, no. 2, 333-338. doi: 10.1016/S1875-5372(15)30030-8

20. M.F. Montemor, A.M. Simões and M.J. Carmezim, Characterization of rare-earth conversion films formed on the AZ31 magnesium alloy and its relation with corrosion protection, Appl. Surf. Sci., 2007, 253, no. 16, 6922-6931. doi: 10.1016/j.apsusc.2007.02.019

21. S.B. Hassen, L. Bousselmi, P. Bercot, E.M. Rezrazi and E. Triki, Improvement in corrosion resistance of magnesium coating with cerium treatment, Rare Met., 2009, 28, 277-283. doi: 10.1007/s12598-009-0055-X

22. H.Y. Su, W.J. Li and C.S. Lin, Effect of acid pickling pretreatment on the properties of cerium conversion coating on AZ31 Mg alloy, J. Electrochem. Soc., 2012, 159, 219225. doi: $10.1149 / 2$.jes113585

23. V.S. Saji, Review of rare-earth-based conversion coatings for magnesium and its alloys, J. Mater. Res. Technol., 8, no. 5, 5012-5035. doi: 10.1016/j.jmrt.2019.08.013

24. S. Pommiers-Belin, J. Frayret, A. Uhart, J.B. Ledeuil, J. Dupin, A. Castetbon and M. Potin-Gautier, Determination of the chemical mechanism of chromate conversion coating on magnesium alloys EV31A, Appl. Surf. Sci., 2014, 298, 199-207. doi: 10.1016/j.apsusc.2014.01.162

25. GOST 9.302-88 Unified system of protection against corrosion and aging. Metallic and non-metallic inorganic coatings. Control methods (Unified system of corrosion and ageing protection. Metal and non-metal inorganic coatings. Control methods), 39 (in Russian).

26. P. Laha, T. Schram and H. Terry, Use of spectroscopic ellipsometry to study Zr/Ti films on Al, Surf. Interface Anal., 2002, 34, no. 1, 677-680. doi: 10.1002/sia.1386 
27. J.C. Woicik, Hard X-ray Photoelectron Spectroscopy (HAXPES), Springer Ser. Surf. Sci., 2016, 59, 571.

28. D.A. Shirley, High-resolution X-ray photoemission spectrum of the valence bands of gold, Phys. Rev. B, 1972, 5, 4709-4713. doi: 0.1103/PhysRevB.5.4709

29. J.H. Scofield, Hartree-Slater subshell photoionization cross-sections at 1254 and $1487 \mathrm{eV}$, J. Electron Spectrosc. Relat. Phenom., 1976, 8, no. 2, 129-137. doi: 10.1016/0368-2048(76)80015-1

30. M. Mohai, XPS MultiQuant: multimodel XPS quantification software, Surf. Interface Anal., 2004, 36, 828-832. doi: 10.1002/sia.1775

31. P.J. Cumpson and M.P. Seah, Elastic scattering corrections in AES and XPS. II. Estimating attenuation lengths and conditions required for their valid use in Overlayer/Substrate experiments, Surf. Interface Anal., 1997, 25, 430-446. doi: 10.1002/(SICI)1096-9918(199706)25:6<430::AID-SIA254>3.0.CO;2-7

32. ISO 4536:1995 Metallic and non-organic coatings on metallic substrates - Saline droplets corrosion test (SD test), 7.

33. ASTM D4541-17 Standard Test Method for Pull-Off Strength of Coatings Using Portable Adhesion Testers.

34. ASTM B117 - 11 Standard Practice for Operating Salt Spray (Fog) Apparatus.

35. T.A. Markley, M. Forsyth and A.E. Hughes, Corrosion protection of AA2024-T3 using rare earth diphenyl phosphates, Electrochim. Acta, 2007, 52, 4024-4031. doi: 10.1016/j.electacta.2006.11.028

36. H.W. Shi, E.H. Han and F.C. Liu, Corrosion protection of aluminium alloy 2024-T3 in $0.05 \mathrm{M} \mathrm{NaCl}$ by cerium cinnamate, Corros. Sci., 2011, 53, 2374-2384. doi: 10.1016/j.corsci.2011.03.012

37. P.A. White, A.E. Hughes, S.A. Furman, N. Sherman, P.A. Corrigan, M.A. Glenn, D. Lau, S.G. Hardin, T.G. Harvey, J. Mardel, T.H. Muster, S.J. Garcia, C. Kwakernaak and J.M.C. Mold, High-throughput channel arrays for inhibitor testing: Proof of concept for AA2024-T3, Corros. Sci., 2009, 51, no. 10, 2279-2290. doi: 10.1016/j.corsci.2009.06.038

38. M. Yu, Y. Liu, J. Liu, S. Li, B. Xue, Y. Zhang and X. Yin, Effects of cerium salts on corrosion behaviors of Si-Zr hybrid sol-gel coatings, Chin. J. Aeronaut., 2015, 28, no. 2, 600-608. doi: 10.1016/j.cja.2015.01.011 